\title{
Language Recognition and Identity Formation in the Khasi and Jaintia Hills
}

\author{
Mereleen Lily Lyngdoh Y. Blah \\ Assistant Professor, Dyal Singh College, University of Delhi, E-mail: mblahs@gmail.com
}

\begin{abstract}
The official use of any language by the administration and employment of the said language by the state whether through educational institutions and administrators as a standard literary dialect, gives it recognition. The Education policy adopted by the British and the choice of English being made the language of instruction throughout the country is made evident in Macaulay's Minute of 1835 and is reiterated again more than a decade later in the Minute of 1847. From the very beginning English was associated with the administration and the benefits that it would bring but they failed to take into account the people who were unfamiliar with it. The categorization and later association of languages with religion, caste, community, tribe and class is evident in the various census undertakings as the official recognition became a determination of its status. In the Census of 1891, the Khasis and Jaintias are relegated as "two groups statistically insignificant", considering the population and the number of people who spoke the languages associated with the communities. The use of the Roman script had by this time been, "thoroughly established" by the missionaries. The first few census data and later writings by indigenous writers helped cement the association of language with the community. The use of the vernacular in the Khasi and Jaintia Hills in Meghalaya, by the earliest missionaries, initially arose more out of necessity and convenience rather than by official decree. The choice and standardization of dialect and script in print however, helped solidify a Khasi identity. This paper seeks to look at the link between recognition of the standard language used in print and identity formation in the Khasi and Jaintia Hills and the relevance of language as a marker of identity today.
\end{abstract}

Keywords: Standardization, Print language, Language and Identity Formation, Khasi Identity.

\section{Language Recognition and Identity Formation in the Khasi Hills and Jaintia Hills}

The issue of identity, especially in relation to colonialism has long been a subject of contestation and debate in the literary realm. Education, religion, language and print culture were arenas which were used to bring about change and exercise control, but these factors also awakened in the colonised people a sense of self. The arrival of the British and missionaries in the Khasi and Jaintia Hills had far-fetched ramifications and brought about distinct shifts in the community and society in the Khasi and Jaintia Hills, not only through conversion, the imposition of a new and standardised educational policy but through the choice of language and script, and printed texts.

In pursuit of their respective objectives, these two institutions, that is, the church and state had a profound impact on Khasi society. It changed the belief system for many converts and opened new doors to those who had passed through the gates of their educational institutions.

(C) AesthetixMS 2020. This Open Access article is published under a Creative Commons Attribution Non-Commercial 4.o International License (http://creativecommons.org/licenses/by-nc/4.o/), which permits non-commercial re-use, distribution, and reproduction in any medium, provided the original work is properly cited. For citation use the DOI. For commercial re-use, please contact editor@rupkatha.com. 
The Asiatic Society of Bengal was founded as early as 1784 with the aim to promote learning for the sake of governance, $e^{i}$ but the Government did not take a keen interest on educating the natives. The first official recognition of the contribution made by the missionaries in the Khasi Hills, in terms of education came in 1853, when A.J.M. Mills, Officiating Judge of the Sudder Court visited the hills and asked William Lewis for a report on the state of education. In his official report to the Government of Bengal, he credits the missionaries for their efforts, following which the government in 1854 , decided that, "the spread of education among the Khasis and other hill tribes in those parts could be most effectively secured by extending help to the Missionary Institution" (Morris, 1996, p. 145).

Prior to the Charter Act of 1813, missionary intervention in the hills was seen as an unwelcome intrusion by the East India Company, as their interests were in "direct conflict with their commercial operations" (May,2012, p.22) Gradually however, the missionaries were given partial access to the north-eastern part of India.

It has to be kept in mind that the arrival of the missionaries though solely for the purpose of gaining converts and enlightening the people, were never really free from control. The East India Company and later the British Crown, kept a close watch on all missionary activity in the Hills. This is made evident from the reports by different officials in the hills and from the letters and meticulous reports of the missionaries themselves. Ethnographic accounts were also commissioned as part of the project of easing administration.

William Carey's Baptist Mission was the first to bear fruit on India's eastern shores with the conversion of Krishna Chandra Pal, the first missionary to be sent to preach the gospel to the Khasisin the foothills of Pandua. Pal, however, returned to Serampore in December 1813, the same year that he arrived.

After almost two decades with no other missionary entering the field, another missionary by the name of Alexander B. Lish, set off for the Khasi Hills and worked there till 1837. Lish opened schools at Cherrapunji, Mawsmai, and Mawmluh, with the assistance of one Joshua Rowe. His too however, was a short endeavour as he left for Calcutta in 1838. Thomas Jones and his wife arrived in the Khasi Hills in 1841. Fifty years later, the Catholic Mission entered the field, in 1890.

The Governor General William Bentinck on Macaulay's advice had through, the English Education Act of 1835, proposed that education was to be imparted in the English language (Vishwanathan, 2012, p.45). Since most of the natives in the Khasi and Jaintia Hills were unfamiliar with the language, education could not be carried out only through the English language, the missionaries had to learn the vernacular, with which the natives were familiar. Out of necessity they adopted what VeenaNaregal calls the "bilingual education policy" (p.4).Upon arrival in 1841, Thomas Jonesof the Welsh Calvinistic Mission, set out to do just that. Thomas Jones, is known as the 'Father of the Khasi Alphabet'. He gave to the Khasis a new script in Roman form. This script with a few additions and corrections by later Khasi writers is used to this day. Jones "settled on the Cherra dialect as the 'middle road', that suits them all." (May, 2012, p. 137).The Khasis had until his arrival used the Bengali and Assamese script.

Khasi is the language spoken in the Khasi and Jaintia Hills where there are many dialectical variations. Print not only simplified but standardized the dialect ofCherrapoonjee. I.M Simon, a noted author and linguist, is of the view that the British had for a long time been stationed at Sohra (the Khasi name for Cherrapoonjee) and the missionaries too were stationed there hence the, "decision to adopt this dialect as the standard for the entire Khasi language area" 
was "more as an historical accident than a planned action" (Chowdhury, 1978, p. 394). Despite variousarguments on the subject what is significant is the emergence of a standard literary language whose status was upheld by recognition and being implemented in various state organizations, including schools and later institutions of higher learning.

A.J.M Mills suggested that it was imperative for the political agent to know Khasi and that English was to replace Bengali as the court language. Following the Jaintia Rebellion, Brigadier General Showers expressed his displeasure at the inability of the government to communicate with the people to whom English was an alien language. Questions on the use of the vernacular as the "language to be used in conveying instructions to the Cossyahs," come up time and again in reports and letters by administrative officials. ${ }^{\mathrm{ii}}$ To this end the discontentment and scepticism of the people in the choice of language which could not be used to trade with people in the surrounding areas, is recorded by Capt. Trotter in his report of 1878 , where they not only complain of the choice of language but ask for a more secular education free of Christian religious dogma. "As the language of schools and of the press, the standard vernacular [became] becomes a necessary qualification for access to the public sphere" (Gupta and Chakravarty, 2004, p.104). Education and the use of the vernacular in print would become key factors leading to an awakening of Khasi writers who would play a major role in the preservation of culture and revival in the coming decades as is made evident in the literary productions drawing on tales of the Khasi folk and their belief system.

What followed the arrival of East India Company Officials, starting with the expedition of 1774, was a gradual series of extensive documentation.Classification and categorisation of people based on religion, race, caste and language was carried on in different parts of the country through means like the census, conducted in various parts of the country. Though the first official all India census was undertaken in 1881, the Annual Report on the Khasi and Jaintia Hills of 187778 mentions a census data collection of 1872 . Revenue collection contributed to this sort of record keeping, as is evident from the reports of the Jaintia Rebellion. Ethnographic records of different tribes and regions across India are made manifest in the different ethnographical accounts undertaken by the Company and then Crown.

The categorization and later association of languages with religion, caste, community, tribe and class is evident in the various census undertakings as the official recognition became a determination of its status. In the Census of 1891, the Khasis and Jaintias are relegated as "two groups statistically insignificant", considering the population and the number of people who spoke the languages associated with the communities, though the use of the roman script had been "thoroughly established". The first few census data helped cement the association of language with the community as a collective. It was not just language, however, it was also the attempt at encoding cultural beliefs in the language that was seen as standard that would lead to the association of language and identity. The numbers would become a reflection of a perceived social reality which is used even today in the assertion for recognition. That the early writers chose to write in Khasi, and about existing cultural beliefs was not an accident. They were an attempt at documenting what was culturally significant to a people whose history was embedded in such narratives. These would also become markers of difference along which the political struggle would ensue.Stoler was right in asserting that it was not just ideology that was imported but also the creation of a class of people shaped by the same. It is this class of indigenous people who recognised the importance of the vernacular language in print in determining the course of a language and the identity of a community. 
To understand the issue of identity today, it is essential to start at the very beginning. The gradual evolution of Khasi identity can perhaps be split into several periods, starting with the conception of the idea of ethnic identity leading to the formation of the SengKhasi, to the relevance of the idea in the present day. The period following 1897, saw the emergence of the new intelligentsia, products of various educational institutions which had been set up since the time of Thomas Jones. The success of these institutions as colonial institutions is evident through the emergence of a new class which constituted primarily of the educated native, the new elite.

It is significant perhaps to note here that the construct of the identity envisioned by the early intelligentsia such as Jeebon Roy, one of the first Khasis to open a press and use the vernacular and print to incite cultural revival and stress on the preservation of Khasi culture, was but a new found idea which had not entered the political realm. It was only after the Bristish had left that constructions of identity gained momentum to find expression in political action. Representation along lines of identity was sought. This period not only saw the emergence of political representation but the rise of the need to determine, "Who is a Khasi?" This is made manifest through the various court cases. "The Election Tribunal" in the case of A.S. Khongphai vs. Stanley D. D. Nichols Roy, "held that it was not merely the purity of blood being the criterion for the determination of who is a Khasi". It was further stated that "a person who assimilates himself with the culture and follows the customs and ways of life can be recognized to be a member of the Khasi tribe, even if he has a mixed blood either on the maternal or the paternal side." (Dev, 2004, p. 36). It is significant to state here that there has been a marked shift from contentions of race, to that based on community as a marker of difference in the present scenario.

By 1947, outward hegemony had been supplanted by inward hegemony, in the form of the Indian State. The setting up of the Autonomous District Councils in 1952, triggered the formation of the Hill States Movement, demanding a separate state for tribals. The massive scaling down of the administration after the British left created a vacuum of sorts which was filled by Assamese officials. The petition by the Assam Provincial Congress Committee, in 1960 to make Assamese the official language, acted as a catalyst. Hegemony was made manifest not only in the attempt to impose a language but was made concrete and visible through the acquisition of land. The riots against the Assamese in 1960, was in a way a general outburst which saw the mobilization of the Khasis along ethnic lines and made real a plethora of real and perceived threats. The Land Transfer Act was soon passed in 1972, which denied any non-tribal the right to acquire land except in a few areas, which "have been classified since colonial times as European wards" (Karlsson 70). The "other" had been established and the attempt at segregation made clear. The next few decades saw various ethnic riots aimed at the effacing of the "other". Language became a shared commonality and a marker of difference.

The period between 1946 and 1970 saw the formation of various tribal and regional organizations starting with the Khasi National Durbar in the early 1920's and regional political organizations such as the Khasi Hills People's Union, All Party Hills Leaders Conference (APHLC) and the Hill States People's Democratic Party (HSPDP). The construct of ethnic identity with language as a symbolic marker became the basis of what was to gradually develop and to be made concrete in to the form of the state, of Meghalaya in 1972. Post 1972 however, there was a growing realization that it was not enough to be politically represented and that control of the cultural and economic sphere was necessary. That mobilization based on ethnicity was gaining momentum is also articulated in emergence of the Khasi Students Union in 1978, an organization which aims at upholding Khasi identity and fighting against the infiltration of outsiders and the formation of the more militant, Hynniewtrep National Liberation Council(HNLC). 
Despite contested claims of a unified Khasi identity and cultural uniqueness, there is no denying the fact that Khasi identity is fractured. The fact that the issue of identity in the Khasi community is still relevant today is made manifest in the passing of the Khasi Social Custom Lineage Act, 1997, which was "adopted by the District Council, in 1997, but did not come into power until 2005 (after it's mandatory approval by the Governor)” (Karlsson, 2011, p. 272). That language and social customs are important markers of this identity, is evident in passing of the Meghalaya State Language Act, 2005, recognising Khasi as an Associate Official Language of the state along with Garo. Even today, various attempts are being made to get the Khasi language included in the Eighth Schedule of the constitution of India.The demand for recognition has been taken up and a committee formed to propose the same. Articles dated over a yearand two years back, with headlines such as, "Khasi in Line for Eighth Schedule" and "Demand for Khasi in Eighth Schedule", appeared in newspapers like The Shillong Times and The Telegraph, respectively, highlight the association of official recognition of the language and the community. In the absence of religion as a common denominator, language and social customs have become the dominant markers against which this recognition is sought.

\section{Notes}

${ }^{\mathrm{i}}$ For more on this please see, Bayly.C.A. Empire and Information: Intelligence Gathering and Social Communication in India, 1780-1870. Cambridge University Press. 1999. Print. p. 54.

${ }^{\text {ii }}$ For more on this, see, Lieutenant Colonel J.C. Haughton's, letter dated 1863, stating his preference for the use of vernacular as it eased administration. The same is corroborated by S.C Bayley, Esq., Junior Secretary to the Government of Bengal, to the Secretary to the Government of India, in the Home Department(No. 362 T. dated the $27^{\text {th }}$ August 1863 )

\section{References}

Abraham, Taisha. (2007).Introducing Post-Colonial Theories: Issues and Debates. Macmillan.

Anderson, Benedict. (2006)Imagined Communities: Reflections on the Origin and Spread of Nationalism. Verso.

Bareh, Hamlet(2003) A Short History of KhasiLiterature.Scorpio Printers.(Original Work Published 1962).

Bayly.C.A.(1999).Empire and Information: Intelligence Gathering and Social Communication in India, 17801870. Cambridge University Press.

Blackburn, Stuart, and VasudhaDalmia.(Eds.). (2004). India's Literary History: Essays on Nineteenth Century. Permanent Black.

Chowdhury, J.N. (1978). The Khasi Canvas.Srimati Jaya Chowdhury.

Cohn, Bernard. (2011)The Bernard Cohn Omnibus.Oxford University Press.

Dev, N.K. (2004). Tradition and Modernity in Khasi Society.Spectrum Publications.

Febvre, Lucien and Henri- Jean Martin.(1976) The Coming of the Book. (David Gerard. Trans.) Verso.

Gupta, Abhijit, and SwapanChakravorty. (Eds.).(2004)Print Areas: Book History in India. Permanent Black 
Gurdon, P.R.T. (2010)TheKhasis. Akanksha Publishing House. (Original work first published in 1906)

Karlsson, Bengt, T.(2011)Unruly Hills: Nature and Nation in India's Northeast.Orient Black Swan Ltd.

Kyndiah, P.R. (2010). No Hill State No Rest. Vesta Book Agengy.

Jyrwa J.F. (1998).Reports of the Foreign Mission of the Presbyterian Church of Wales on Khasi Jaintia Hills: 1864-1899. Christian Communication Department.

May, Andrew J.(2012). Welsh Missionaries and British Imperialism. Manchester University Press.

Morris, John, Hughes. (1996)The History of the Welsh Calvinistic Methodists, Foreign Mission: To the End of the Year 1904. Indus Publishing.

Naregal, Veena.(2001).Language Politics, Elites, and the Public Sphere.Permanent Black.

Roy, Jeebon. (1932)KaNiam Jong Ki Khasi.RiKhasi Press.(Original Work Published in 1897)

Said, Edward.(2003) Orientalism.Penguin. (Original Work Published in 1977)

Simon. I.M. (1980) Meghalaya.Government of India Press.

Singh, Kynpham.(1972)KaJingim U BabuJeebon Roy ("The Father of Modern Khasis”). RiKhasi Press.

Stadler, G., and S. Karotemprel.(1980)(Trans. \&Eds.)History of the Catholic Missions in North East India(1890-1915). VendrameMissiological Institute.

Sten, H.W. (1980) KaHistoriKaKtienKhasi. Scorpio Printers.

Stoler, Ann Laura.(2002). Colonial Archives and the Arts of Governance.Archival Science 2: 87-109.

Syiemlieh, David. (1989). British Administration in Meghalaya: Policy and Pattern. Heritage Publishers.

Trotter, Captain F.Report on the Administration of the Khasi and Jaintia Hills for the Year 1877. Calcutta. Scholar Select.

Vishwanathan, Gauri.(2012) Masks of Conquests: Literary Study and British Rule in India. 1989. New Delhi: Oxford University Press.

Marbaninag, Bankitlang. (2018, June 23)Demand for Khasi in Eight Schedule. The Telegraph. https://www.telegraphindia.com/north-east/demand-for-khasi-in-eighth-schedule/cid/1452709

(2019, March 21) Khasi in Line for Eight Shedule: KAS. The Shillong Times.https://theshillongtimes.com/2019/03/21/khasi-in-line-for-eighth-schedule-kas/

General Report on the Census of India 1891.(1893). Eyre and Spottiswoode.

censusindia.gov.in

Archival Sources

West Bengal State Archives. Home Proceedings.No. 362T. 